\title{
ASSESSMENT OF RECREATION CARRYING CAPACITY OF ILE-ALATAU NATIONAL PARK IN KAZAKHSTAN
}

\author{
Zhannat ALIYEVA* \\ Al Farabi Kazakh National University, \\ 050040, Al-Farabi ave., 71, Almaty, Kazakhstan, e-mail: ZAliyeva@kaznu.kz \\ Mereke SAKYPBEK \\ $\mathrm{Al}$ Farabi Kazakh National University, \\ 050040, Al-Farabi ave., 71, Almaty, Kazakhstan, e-mail: M.Sakypbek@kaznu.kz \\ Aliya AKTYMBAYEVA \\ Al Farabi Kazakh National University, \\ 050040, Al-Farabi ave., 71, Almaty, Kazakhstan, e-mail: A.Aktymbayeva@kaznu.kz \\ Zhanna ASSIPOVA \\ Al Farabi Kazakh National University, \\ 050040, Al-Farabi ave., 71, Almaty, Kazakhstan, e-mail: Zh.Assipova@kaznu.kz
}

\author{
Sabirzhan SAIDULLAYEV \\ Narxoz University, 050035, \\ Zhandosov Str, 55, Almaty, Kazakhstan, e-mail: Saidullayev@narxoz.kz
}

\begin{abstract}
Citation: Aliyeva, Zh., Sakypbek, M., Aktymbayeva, A., Assipova, Zh., \& Saidullayev, S. (2020). ASSESSMENT OF RECREATION CARRYING CAPACITY OF ILE-ALATAU NATIONAL PARK IN KAZAKHSTAN. GeoJournal of Tourism and Geosites, 29(2), 460-471. https://doi.org/10.30892/gtg.29207-482
\end{abstract}

\begin{abstract}
Recreation carrying capacity is an important concept in park and protected area management for estimation of optimum recreation use and sustainable tourism management. In fact, the recreation carrying capacity concept has been used as a method to regulate the maximum number of visitors to a specific recreational site in many occasions. The Ile-Alatau national nature park in Kazakhstan is located close to Almaty, largest city of Kazakhstan and it is a popular place for tourism activities and regular weekend tours. In the Ile-Alatau Nature Park, fauna and flora are characterized by high diversity and concentration in a relatively small area. By using Framework for Assessment Carrying Capacity for Protected Areas, this manuscript aims to estimate the recreational carrying capacity of the Ile-Alatau nature park in Kazakhstan. Result showed that the estimated recreational carrying capacity is between 67-70 people per ha. This number is higher than actual average park visitation. This study outcomes have important implications for the management and can improve long-term planning and decision-making process of the Ile-Alatau National Park.
\end{abstract}

Key words: national park, recreation carrying capacity, sustainable tourism, Kazakhstan

\footnotetext{
* Corresponding author
} 


\section{INTRODUCTION}

The problems of assessment of recreational capacity of the national park for tourism purpose have become more relevant. This is due to the need to solve two interrelated and contradictory tasks such as ensuring a complete rest of visitors and protecting environmental nature in recreation areas. Abernethy (2001) defines recreational carrying capacity as an instrument which support the specific impacts for sustainability assessments of tourism activities and this instrument can be used as a method to regulate the maximum visitation to a specific site at any environment. Nakajima \& Ortega (2016) defined four types of the carrying capacity including i) economic; ii) psychological; iii) environmental or ecological; and iv) social.

According to Koshim et al. (2019) economic carrying capacity defines the impact of tourism through economic indicators. Vujko et al. (2017) and Saparov et al. (2017) mentioned that psychological carrying capacity examines the level of visitors' satisfaction by destination and service. Iskakov \& Medeu (2007) indicated that environmental carrying capacity regards the impact of tourism activities on environment. Some authors give specific definition of ecological carrying capacity is the maximum use that the biota or the physical processes of an area can withstand before becoming unacceptably or irreversibly damaged (Singtuen \& Won-In, 2018). Finally, McLachlan \& Defeo (2017) viewed on social carrying capacity as the reaction of local community to tourism.

In addition, there is recreational carrying capacity. Erdavletov (2000) defines the recreational capacity of a territory as the maximum allowable number of visitors who can stay in that territory without causing a pressure on the sustainable natural balance and thereby worsening the conditions of rest. In the case of a tourist route, this concept is defined as carrying capacity without violating safety regulations. In context of national park's carrying capacity, the recreational capacity is defined as an area for vacation, which includes a national park determines the maximum number of sports and recreational tourists who can stay at the same time without compromising the natural environment sustainability and normal life rhythm of the region (Sharma \& Kamal, 2019). CupulMagana \& Rodriguez-Troncoso (2017) argue that using the carrying capacity concept in a touristic area, may generate a satisfactory experience for the tourism with an acceptable or minimum impact on the resource of the protected area. Iskakov \& Medeu (2007) and Atanga (2019) proposes to calculate the recreational carrying capacity in the number of visitors per day in recreational area or recreational facility for a certain period of time.

Each territory has its own carrying capacity and permissible environmental load, depending on the ability of the reproduction of natural resources, as well as to a large extent related to the presence of effective environmental protection infrastructure. Therefore, optimization of the interaction of production and natural systems involves the alignment of the scale and forms of management with the natural capabilities of the territory (Koshim et al., 2018). When comparing the capacity of the ecologicaleconomic system with the actual environmental load, it is possible to determine the degree of imbalance of the territory from the standpoint of economic development, the social sphere and environmental degradation. Such comparison develops a set of measures to harmonize the pace of development of the ecological-economic system with its ecological capacity. The tourism industry, on the one hand, places high demands on the quality of the environment, on the other it is associated with large anthropogenic pressures on the environment. Consequently, the development of recreational activities in the territory must be developed in accordance with the principals of sustainability, which also include the determination of recreational carrying capacity (Zhang et al., 2016). Many studies have been conducted concerning different aspects of the carrying 
capacity for national parks and protected areas (Papageorgiou \& Brotherton, 1999; Manning, 2001; Janeczko \& Gucma, 2015). Many of these studies devoted to the standards and assessments of the recreational carrying capacity of natural parks (Butler, 1996; Saveriades, 2000). Many standards of carrying capacity are based on data from observations or are derived empirically based evidence.

For example, there are evaluation results from studies of the Rosgiproles Institute, where permissible recreational loads depending on the functional zones were determined in the following limits: zone of quite rest - up to 5 visitors per ha; zone of recreation - up to 20 visitors per ha; zone of active recreation area - from 20 to 100 visitors per ha (Rosgiproles Report, 2009). In Kazakhstan, there is no universally accepted methodology to quantify the carrying capacity of national parks and protected areas. However, a longterm management plan for each park was prepared to determine the conditions of access, protection, development, and management. Furthermore, these plans were not utilized and functioned only as inventory tools when needed. They included nothing about visitors, their management or most of the recreational experiences available. Based on existing assessment methodologies, this manuscript aims to estimate the recreational carrying capacity of the Ile-Alatau national park in Kazakhstan.

\section{STUDY AREA}

Kazakhstan is landlocked and ninth largest country in the world, and located in Central Asia with rich historical, cultural and natural resources (Karatayev et al., 2016; Rivotti et al., 2018). The geographic positioning of country result in a unique combination of different fauna and flora elements, and underpins the significance of the biodiversity of Kazakhstan and the need for its conservation in the regional context (Karatayev \& Hall, 2017). About $3 \%$ of the world's known flora and $5 \%$ of the world's known fauna can be found in the country. Developing networks of specially protected nature areas is one of the means to provide long-term conservation of biological and landscape diversity of national, regional, and global importance (Valeyev et al., 2019).

Kazakhstan has been carrying out sequential actions towards the ecological network establishment inside the country as well as regionally. The national protected nature system is established and developing based on national legislations and international agreements ratified by Kazakhstan. In this enormous territory, specially protected natural territories occupy about 9\% of the country's area or 24.7 million hectares. Currently, there are 13 state nature parks, 66 state nature reserves, 9 state natural monuments, 2 state nature habitat and 2 transboundary protected areas. The main regulatory legal acts regulating tourism activities in protected areas are the Law of the Republic of Kazakhstan on specially protected natural territories, the Land Code of the Republic of Kazakhstan, and the Forest Code of the Republic of Kazakhstan. National parks have developed in Kazakhstan only in the last 30 years. The first national park was established in 1986. The main idea of creating national parks is to preserve the unique nature while providing people with opportunities to engage in recreational activities, to get knowledge about nature. Natural parks and tourism are interrelated, while there is a need for tourists to travel to ecologically clean areas of the Earth.

The object of this research is the Ile-Alatau national natural park. The natural park is located on the northern macrohillside of the ridge Trans-Ili Ala-Tau, which is the part of Northern Tyan Shan physical geographic province. The ridge of Trans-Ili Ala-Tau is complex and by its topology relates to the northern spur of Tyan Shan. The territory is peculiar of vertical zonality or belt character of relief, which specified a wide variety of landscapes. The Ile-Alatau Natural Park was established following a decree by the 
Government of the Republic of Kazakhstan dated February 22, 1996 with the 164450 ha territory. Later, the territory of the park was extended to 199252 ha. This territory is currently divided into 4 zones. First zone is conservation area with 62137 ha $(31,2 \%)$. The defining function of this zone is the preservation fauna, flora and biodiversity. The second zone is environmental stabilization zone with 16412 ha $(8,2 \%)$. The main function of the zone is to provide conditions for the preservation of natural complexes and objects, restore disturbed natural complexes and objects of the nature reserve fund. The third some is area of recreational activities with 15408 ha $(7,8 \%)$. The main function of the zone is to ensure the conservation of natural complexes and objects of protection with simultaneous strictly regulated use for tourist and recreational purposes. The zone is divided into sections of regulated short and long stay of tourists and recreation of visitors to the park. The fourth zone is limited business area with 105295 ha $(52,8 \%)$. It is intended for the placement of administrative facilities associated with the activities of the Ile-Alatau park, as well as individuals and legal entities on the basis of lease agreements with the main land user in accordance with the country's legislation.

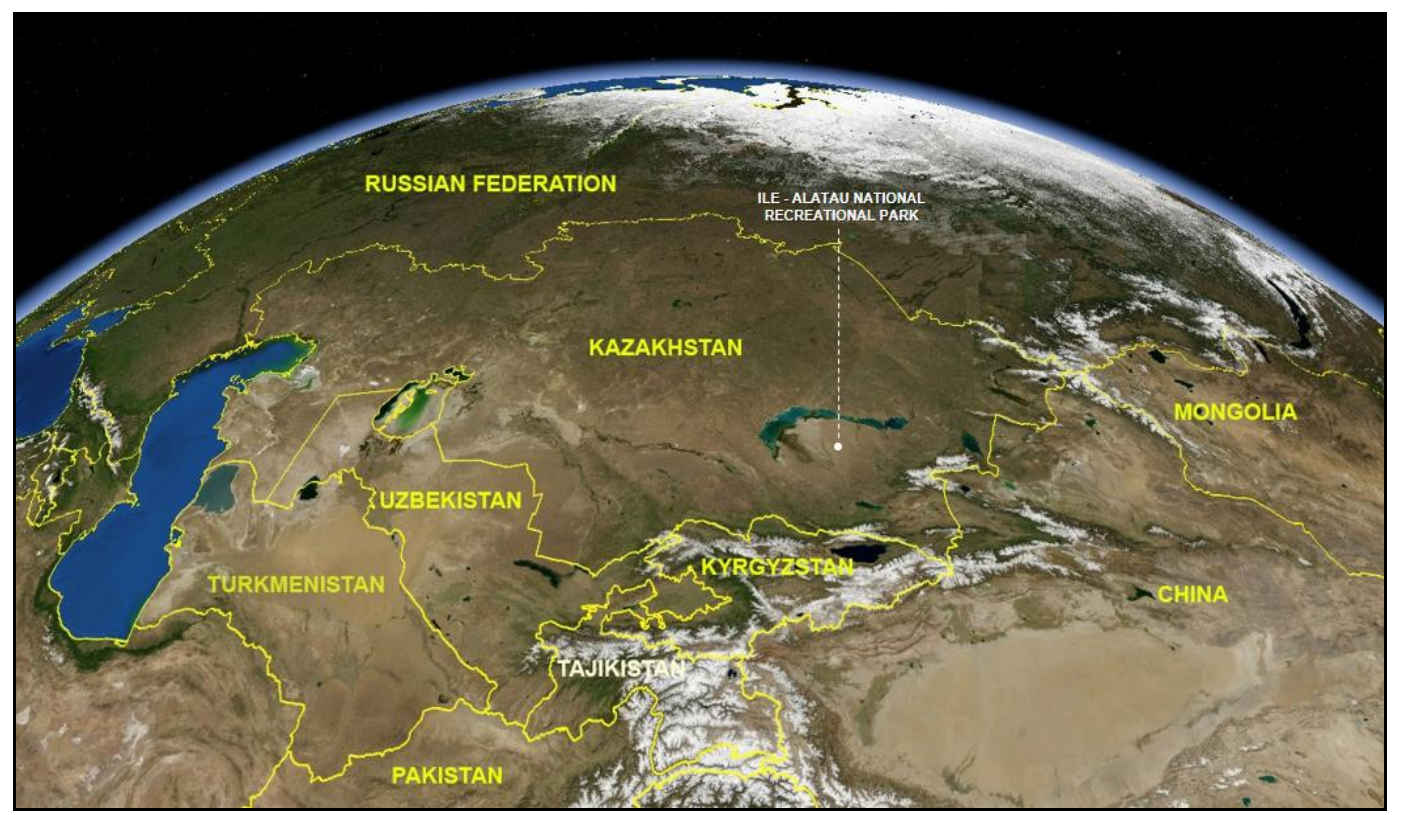

Figure 1. The location of Ile-Alatau national recreational park in Kazakhstan

\section{GEOGRAPHICAL AND RECREATIONAL CHARACTERISTICS}

The basic pattern of distribution of vegetation, soils and wildlife in the Ile-Alatau national recreational park is characterized by vertical zones. The boundaries of vegetation zones coincide with the boundaries of soil areas:

Foothill-low mountain steppe belt. The steppe zone covers the whole territory of foothills and low mountains. Steppe vegetation covers the slopes of foothills and low mountains of various exposures, as well as the bottom and the dry inter-mountain valleys of the foothills. Dominant vegetation is steppe fescue-forb and sagebrush-grass community. They are dominated by fescue striated, found in large quantities sedge lignocaine, Kochia, Artemisia, etc. The vegetation of these barrens is low and only in spring it has bright green color, which is already the middle of summer, becoming yellow- 
grey. Stony-gravelly slopes of low mountains are covered with sparse vegetation of sagebrush-grass and fescue-sagebrush type. These are dry steppe with a predominance of Artemisia, teresken, Kohei, feather grass, fescue, etc. The characteristic feature of this zone is the extensive development of bushes, which are ubiquitous, almost completely covering the entire system of hills, with the exception of ravines. Shrubs are represented mainly by the following species: dog rose, honeysuckle, Spiraea, cotoneaster, ash tree, and barberry. The soils of this zone vary. At the top of the belt and within the lowlands of the mountain there is common, brown soil, and in the lower part - light brown soil. The soil is mostly thin, often stony and gravelly. The structure is lumpy-granular. By the mechanical composition soils there are stony and clayey.

Mid-mountain forest-meadow-steppe zone. This belt occupies a large area in the range of absolute height from $1100-1300$ to $2000-2200 \mathrm{~m}$. Forest dominant tree species here are walnut and juniper. The densest forests with a small number of shrubs, welldeveloped moss and sparse herbaceous cover grow on steep northern slopes.

Juniper forests are unique and have ecological, sanitary-hygienic, health, and soil conservation value. On the floodplains the stands of ash, birch, poplar and willow grow, and on terraces and mountain slopes hawthorn. Shrubs are found everywhere on the slopes of mountains and among forests. Characteristic species are - cherry shrub, cotoneaster, spiraea, honeysuckle, wild rose, barberry, aflatunia, abelia, etc. The soils of the forest zone here are mountain forest black and dark-colored soils. These soils are spread mainly on the slopes of northern exposition. Forming on steep slopes, mountain-forest soils are usually gravelly and stony.

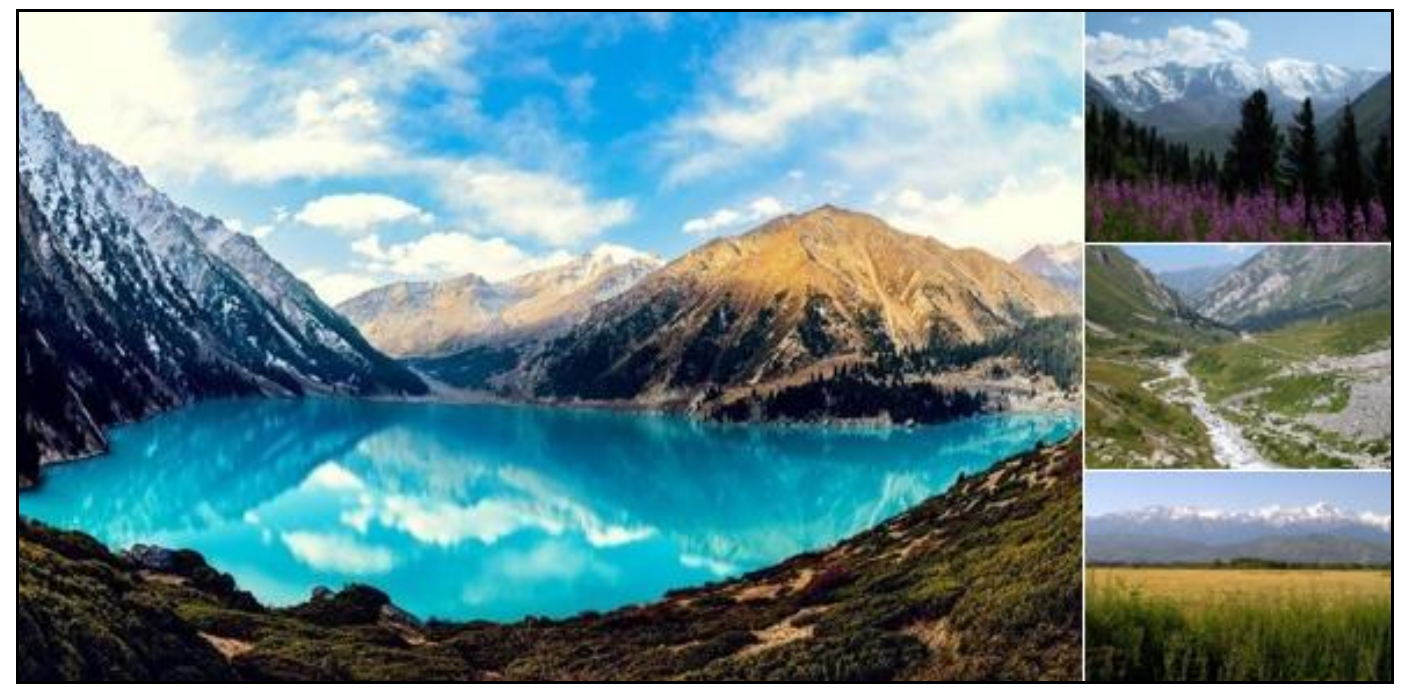

Figure 2. The main physico-geographical and recreational characteristics of Ile-Alatau park

Sub Tien-Shan zone. The sub Tien-Shan belt is located above the forest belt, within altitudes from 2000 to $2500 \mathrm{~m}$, sometimes $3000 \mathrm{~m}$. With the change of the altitude the forest-meadow-steppe zone gradually passes into the sub zone, characterized by diverse natural conditions. The climate is temperate-cold and less humid than in the forest belt. The sub Tien-Shan meadows have rich herbaceous species composition. The predominant types are: Jerusalem sage, globe-flower, geranium Collina, cuff fluffy, blue forget-me-not, Highlander and a number of other medium grass species with large and colorful 
flowers. The herbaceous layer is typically dense with the coverage of $80-100 \%$ (Sakypbek \& Aktymbayeva, 2017). Soil profiles become fairly powerful compared to the previous belt. They are better differentiated into horizons and contain more humus, which is associated with increased activity of microorganisms. The fir and spruce forests grow here. Depending on the degree of moisture these soils under fir and spruce forests can have two subtypes: a) dark-colored peaty ordinary in and dry fir and spruce stands; b) dark peaty leached in more humid fir and spruce stands.

Tien-Shan zone. This belt occupies the most elevated part of the lands with absolute heights of 2500-3500m. At the whole northern macroslope of Trans-Ili AlaTau there are more than 300 glaciers, total area of which more than $300 \mathrm{sq} . \mathrm{km}$. The glaciers are frequently surrounded with a border of massive clumpy moraines, which are tending down the valleys down to the altitude of $2750 \mathrm{~m}$ (Nesterova et al., 2017).

The Tien-Shan zone is widespread, but is not a continuous strip, as in many places covered with rocks, talus or destroyed by mudflows. Vegetation on Tien-Shan meadows is short-grass. Due to high altitude and low temperature, the vegetation does not have time to complete a full life cycle within a short summer season. All the plants are short, and their root system is shallow. Under humid conditions between hills and floodplains there is a dense continuous cover of sedge, bluegrass purple, viviparous knotweed, Albert buttercup. Here the characteristic of the Tien-Shan zone are forb -grass meadows, and in the conditions of high humidity - meadows with predominance of sedges with a dash of herbs. Large areas of the Tien-Shan zone are cliffs, talus, uncovered by vegetation. Soils of the Tien-Shan belt are poorly developed. Severe natural (climatic) conditions of this belt are the reason that the soil formation processes proceed very slowly. The Tien-Shan soils are generally thin, weakly differentiated into horizons, mostly of low humus and gravelly. Low temperatures inhibit the decomposition of organic residues to humus, resulting in the Tien-Shan mountain-meadow semi-peaty soils.

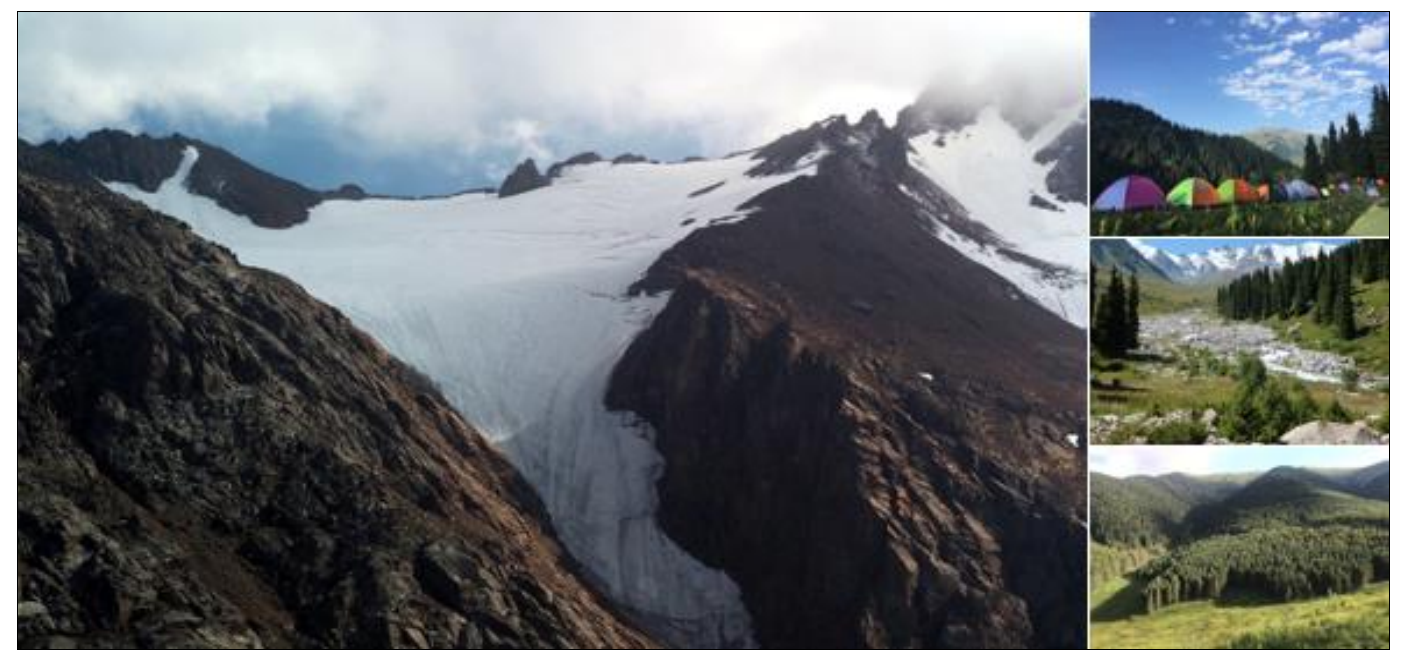

Figure 3. The main physico-geographical and recreational characteristics of Ile-Alatau park

By climatic features the territory relates to Trans-Ili subregion, which is notable for moderately warm climate with a late spring-summer maximum of sediments. The vertical zonality of the climatic features is vividly expressed. Their most appreciable displays are inconvertible temperature drop and magnification of intensity of solar 
irradiation, annual and seasonal volume of atmospheric precipitation in accordance with magnification of terrain clearance altitude. Endurance of solar light is above 2000 hours per year. The mountain band of middle altitude is notable for gentle winds (1.5 - 2 $\mathrm{m} / \mathrm{s}$ ). During short-term periods of time in low and high-mountainous zones the speed of wind may exceed $20 \mathrm{~m} / \mathrm{s}$. In winter the inverse of temperature of air diffusing up to the altitude of $2000 \mathrm{~m}$ has place. At the altitude of $800 \mathrm{~m}$ the mean temperature of January is $-6.8^{\circ}$, at the altitude $1529 \mathrm{~m}$ is $-3,7^{\circ}$, and at the altitude of $1942 \mathrm{~m}$ is $6.3^{\circ}$ (Nesterova et al., 2017). The summer in low altitude part is long-term and hot.

Mean temperature of July is $20-22^{\circ}$. As altitude increases the summer becomes shorter and more cool. In the middle altitude part mean temperature of July is $10-15^{\circ}$, and in high-mountainous part is $5-10^{\circ}$ (Vukolov \& Woodward, 2010). The volume of sediments with altitude is being increased: from $616 \mathrm{~mm}$ (at the altitude of $800 \mathrm{~m}$ ) up to $1000 \mathrm{~mm}(3500 \mathrm{~m})$. With altitude endurance of conservation of snow overlying strata and its altitude also is increased. In a low part the snow is laying 190 days, and its altitude in the spring reaches $100 \mathrm{~m}$. In high-mountainous bands the snow lays more than 250 days, and its altitude exceeds $100 \mathrm{~m}$ (Iskakov \& Medeu, 2007).

Features of natural climatic conditions specify forming of intensive surface sink and advanced hydroplot network. By nature of feeding and drains all rivers of Trans-Ili are subdivided into three types: high-altitude glacial, middle-altitude and low-altitude. The largest are the rivers of the first type. Among them are the rivers Chemolgan, Kaskelen, Aksai, Major and Minor Almatinka, Talgar, Esik, Turgen. It is the rivers of glacial feeding, which are deep and have great area of water collection. High standing of water in these rivers has place for a long time - from the beginning of thaw of snows (in April) up to the end of August. The depth of their valleys reaches $800-1000 \mathrm{~m}$ (Nesterova et al., 2017). Maximum average annual rates of stream are observed scored at the rivers of Talgar $-10.3 \mathrm{~m}^{3}$ per year, Turgen $-7.04 \mathrm{~m}^{3}$ per year, Esik $-4.99 \mathrm{~m}^{3}$ per year. Middle-altitude rivers, the sources of which are located at the altitude of less than $3000 \mathrm{~m}$, are fed mainly by atmospheric precipitation and underground waters. In most cases they take originating from springs getting out of tectonic faults and fractures of bedrocks (Begembetov \& Vinogradova, 2006). Most of them are small (15-20 km) highland rivers with high inclination of channel and rapid stream. The third type includes many originating in low-altitude band of the ridge of the shallow seasonal rivers, in which water appears only in spring, and in summer they dry up. There is a number of lakes of various sizes in the territory. By origin and aqueous mode there are the following types of lakes: glacial, starved, starved retaining and landslip tectonic.

The sizes of them are changing from $100-200 \mathrm{~m}$ in a diameter up to $1-1.5 \mathrm{~km}$. To the latter type the lakes of landslip tectonic origin are related - Esik and Major Almaty lake. Landslip dam of the former one had been destroyed during intense mudflow of 1963 (Vukolov \& Woodward, 2010). The breaking have barred later artificially and again formed lake has considerably smaller area. Level of the second lake is artificially uplifted up by a dam, and it is a potable water storage for Almaty, thus, the territory which is included in national park is a place of forming of the aqueous drain providing water supply of settlements and agricultural zone of piedmonts.

\section{RECREATIONAL ACTIVITIES}

The main goals and objectives of the national park are to conserve and restore unique natural complexes and provide people with various recreational activities for both summer and winter holidays. For these purposes special sites are allocated, which are under recreational accomplishment. 170 places for picnic, in a summer time 10-15 
yurts and tents camping's are working, historical and ethnographic visit-center KieliBulak is under re-construction. There are 22 tourist routs and 5 ecological tracks (Nesterova et al., 2017). In 2017, about 140000 people spent time in the national park. 69 organized tourist groups where 3450 people were accepted. More than 5000 copies of the booklets, notes for the tourists attending national park are issued (Sakypbek \& Aktymbayeva, 2017). The growing tendency of outdoor recreation among Kazakhstani residents have both positive and negative impact on the national park activity.

Positive impact consists an income, infrastructure development and etc. Negative impact characterized by increased pressure on the natural systems of the park, increasing general pollution of the territory, air basin and degradation of ecosystems due to increased anthropogenic load, insufficient attention to the problem of garbage collection and general pollution of the territory and lack of effective monitoring of recreational and tourist activities, which does not allow regulating the recreational load and redistribute flows of tourists in order to preserve the ecosystems of the Ile-Alatau park. However, an uncompleted inventory of flora and fauna reduces the attractiveness of the territory for tourists of a special scientific and scientific-cognitive orientation.

Recreational loads for the Ile-Alatau park were developed during the preparation of the project "Correction of the feasibility study of the Ile-Alatau National Natural Park in terms of developing a master plan for the development of infrastructures" in 2013 (Geldiyev, 2013). According to this document, the existing tourist routes of the Ile-Alatau park of different directions can accommodate 8879 visitors per month, 36040 visitors per year. But according to the Park report, in 2018 the Ile-Alatau park was visited by 202351 people. Because of the problems of segmentation of groups of tourists, it is unclear the number of tourists who used hiking routes. Due to lack of control over the number of tourists on popular sites, it is necessary to reconsider the recreational load on the park. As all national parks, Ile-Alatau park has a management plan in order to conserve and protect biodiversity and nature of the territory to use the natural resources in appropriate way. However, there are currently no carrying capacity data for the primary sites. At the same time when calculating the carrying capacity of the national park, it is proposed to consider not only the number of visitors who are vacationing, but also the residents living in the given territory. In the total area of the territory for which the recreational load is provided, there are included, in addition to specially protected territories, lands occupied with agricultural production, residential and recreational buildings, etc.

\section{RESEARCH METHOD}

McCool \& Lime (2001) suggests that development objectives are determinant in the calculation of carrying capacity and can help manage the inevitable negative impacts from leisure activities; whilst Martin \& Uysal (1990) outlined that the carrying capacity provides the optimum level upon which resources can deteriorate or damage to the ecosystems are irreversible, providing a mathematical formula of how many tourists are enough. Papageorgiou \& Brotherton (1999) indicated that despite several criticisms, carrying capacity assessment remains a powerful concept that can be used for planning and management of sustainable tourism; Davis \& Tisdell (1995) reported that apart from outlining all factors that limit tourism growth, the concept of carrying capacity also indicates compensatory tools to manage tourism flows to a destination; whilst Shelby \& Heberlein (1984) indicated that this concept should be seen as a positive and dynamic prism contemplating the temporal space as a basic value for implementation of sustainable beach management principles. To assess the recreational carrying capacity, the Carrying Capacity Assessment for Protected Areas framework developed by Saarinen 
(2006) and further explained and applied by several other authors (Maltceva, 2007; Akimova et al., 2011; Zelt \& Kireev, 2012) was used. This framework attempts to establish the maximum number of visitors that an area can have based on the physical, biological and management conditions of the area, considering three main levels: the physical carrying capacity (the maximum number of visitors that can physically fit into a defined area over a particular time), the real carrying capacity (the maximum permissible number of visits to a specific site) and the effective or permissible carrying capacity (the maximum number of visits that a site can sustain considering the management capacity).

Based on existing methodological tools, the recreational carrying capacity was determined by the following formula, provided by Saarinen (2006):

$$
\sum_{\text {max }, \mathrm{t}}=\frac{\mathrm{M}_{\text {load }}}{\mathrm{s}_{\text {area }}} * \mathrm{k}^{*} \mathrm{f}^{*} \mathrm{~g}^{*} \mathrm{j}^{*} \mathrm{q}
$$

Formula 1, where $\Sigma_{t}$ - index of a recreational carrying capacity of the territory defined as the maximum permissible number of visits to a site, once the corrective factors derived from the particular characteristics of the site have been applied to the physical carrying capacity; $M_{\text {load }}$ - maximum and minimum load of the territory, visitors; $S_{\text {area }}$ - total area of the territory for recreation, ha; $k, f, g, j, q$ - a system of correction factors that consider the degree of development of the ecological infrastructure and the level of development of the recreational area.

The maximum and minimum load of the territory was determined using the following formula (Saarinen, 2006):

$$
M_{\text {load }}=\frac{Q_{1}+Q_{2}+Q_{3}+Q_{4}}{4}
$$

Formula 2, where, $Q_{1}$ - permanent residents' number; $Q_{2}$ - number of park employees; $Q_{3}$ and $Q_{4}$ - number of seasonal visitors.

It is important to consider corrective factors are closely linked to the specific conditions and characteristics of each site and obtained by bio-physical, environmental, ecological, social and management variables. They are expressed as the following formula (Sayan \& Atik, 2011):

$$
g=g_{y} \times g_{c}
$$

Formula 3, where $g$ is the coefficient of the corrective factors of the territory, $g_{y}$ is the limiting magnitude of the variable, and $g_{c}$ is the total magnitude of the variable.

\section{RESULT AND DISCUSSION}

The method outcomes defined that the average index of the recreational capacity of Ile-Alatau park will be approximately 67-70 visitors per ha. Many visitors can be permanently in the territory of the Ile-Alatau park, the rest should only temporarily stay no more than 8 hours. Also, according to formula, the minimum carrying capacity is one visitor per hectares. These numbers are only theoretical and incorporating the correction factors. By determining the usage level of an area without exceeding certain levels, the physical carrying capacity has been extensively viewed as a panacea for recreational park management and as a tool to reduce impacts from tourism. However, there is a degree of subjectivity when identifying the desired level of each indicator and the difficulties of establishing the relationship between number of visitors and each indicator. Another 
point that generates controversy around recreational capacity is that it does not consider the level of interaction between tourists themselves and between tourists and local communities. Although the carrying capacity has significantly higher current number of visitors, an important aspect should be included: the management capacity of the park.

To measure management capacity, it is necessary to address several variables such as the juridical background, policies and regulations, equipment, personnel, funding, infrastructure and facilities and the management capacity would be defined as the best status or conditions that park administrators should keep in order to develop their activities and meet proposed objectives. Furthermore, tourism as a vehicle of culture, prosperity and peace must conserve without damaging, protect without plundering and create without destroying. Especially in nature protected areas, this statement achieves greater significance if parks as eco-social landscapes in which use patterns, perceptions and behavioural attitudes are completely dependent on the users or tourists. As a result of these patterns, there is a need to preserve and protect these fragile natural sites.

Regarding sustainable management of park, since 1991, a modern and effective legal framework has been created, a system has been developed for attracting additional sources of funding for nature reserves and national parks, and their geographical network has expanded. Since 2010 a specialized department has been created under Ministry of Environmental Protection, which is engaged in direct management of the system of state nature reserves and parks. Constructive steps have been taken to adapt the scientific activities of the reserves to the conditions of the modern scientific community. The capabilities of the protected areas have increased. The fragmentation in the management of national parks have been eliminated. New conceptual approaches to the development of territorial nature conservation at the national and regional levels have been developed. Public environmental organizations began to play a fundamentally new role in supporting parks. And most importantly, in extremely difficult political and socio-economic conditions, it was possible to preserve and expand the system of specially protected natural territories, primarily state natural reserves and national parks. A wealth of practice has been accumulated in the world, showing that the increase in the attendance of protected areas is not necessarily the destruction of natural complexes and the invasion of the natural course of natural processes. On the contrary, this phenomenon have a positive effect on the conservation of nature and cultural heritage, including a living traditional culture. In this regard, further study of the role of tourism in the activities of protected natural areas is necessary including a detailed analysis of the differences in potential and its implementation in nature reserves and national parks; the relationship of tourism with other functions of these environmental institutions; its impact on the management of protected areas. This, in turn, will allow us to formulate a range of tasks for managing the development of ecotourism in accordance with the most important goals of the functioning of protected areas.

Finally, taking into account increased recreational pressure on park, in order to obtain objective information necessary for making operational decisions and long-term programs for the prevention and elimination of the negative consequences of various types of use of natural resources, Ile-Alatau national park is recommended to conduct periodic inventories and systematic monitoring of the state of natural complexes and objects, or their monitoring. Monitoring programs in national park may include monitoring the status of: ecosystems that play a special role for the survival of rare species of animals and plants; biodiversity and qualitative composition of biota (flora and fauna), primarily vertebrates and vascular plants; number of rare species of plants and animals included in the Red Book or regional lists of specially protected species; number of 
hunting and commercial animal species, especially valuable medicinal plants and other species of significant economic or social importance; species especially vulnerable due to the formation of mass clusters (colonial birds, marine mammals, etc.); edificatory species. It is advisable to conduct observations separately for functional zones, periodically summarizing these data for the national park as a whole. Monitoring should be carried out according to specially developed programs to all national parks and state nature reserves. A complete inventory of plant and animal objects should be planned by the Ministry of Environmental Protection of Kazakhstan at the request of national parks. These works should be carried out by specialized state organizations with a frequency of 10-15 years.

\section{CONCLUSIONS}

The recreational carrying capacity concept is a dynamic concept which depends on variables that have to be measured and can change with time. This study outcomes have important implications for the management and can improve long-term planning and decision-making process of the Ile-Alatau National Park. This paper made assessment of recreational carrying capacity assessment in the Ile-Alatau National Park. The result found that Ile-Alatau park could accept more tourists than existing number of visitors.

To do so it should be improved the state of current infrastructure such as parking places, roads, camping zones etc. However, defining the optimum number of visitors is not the end and there is a need of applying other frameworks that based on the upper limits of acceptance can help in the process of identifying the load or the level of impact that the Ile-Alatau National Park will sustain and codes of conduct that park visitors should follow. Currently, camping places as well as hiking trails became popular in IleAlatau National Park. And the damage for the biodiversity and environment of the national park cause from the campers' side. Also, a weak system of collection and sorting of waste, unformed responsible attitude of the majority of tourists to the environment will not be allowed to take more than existing number of tourists. While the development of tourism is at the initial stage, it is necessary to take a course on sustainable development.

As a tool for assessing and regulating the use of recreational facilities, the procedure for environmental monitoring of the territory should be recommended.

\section{REFERENCES}

Abernethy, V.D. (2001). Carrying capacity: The tradition and policy implications of limits. Ethics in Science and Environmental Politics, 9, 9-18.

Akimova, T., Batonyan, V., Moiseyenkov, O. \& Khaskin, V. (2011). Types of ecological and economic zones. Moscow [in Russian].

Atanga, R. A. (2019). Stakeholder views on sustainable community-based ecotourism: a case of the Paga crocodile ponds in Ghana. GeoJournal of Tourism and Geosites, 25(2), 321-333.

Begembetov, A.A. \& Vinogradova, V.P. (2006). The role of ecotourism in preservation of biodiversity of ecosystems in Ile-Alatau state national park. Almaty [in Russian].

Butler, R. W. (1996). The concept of carrying capacity for tourism destinations: dead or merely buried?. Progress in tourism and hospitality research, 2(3-4), 283-293.

Cupul-Magaña, A. L., \& Rodríguez-Troncoso, A. P. (2017). Tourist carrying capacity at Islas Marietas National Park: An essential tool to protect the coral community. Applied Geography, 88, 15-23.

Davis, D., \& Tisdell, C. (1995). Recreational scuba-diving and carrying capacity in marine protected areas. Ocean \& Coastal Management, 26(1), 19-40.

Erdavletov, S. (2000). Tourism geography: History, theory, methods, practice. Almaty [in Russian].

Geldiyev B. (2013). The adjustment of the technical and economic assessment in the elaboration part of the general plan of the infrastructure development. Almaty [in Russian].

Iskakov N., Medeu A. (2007). Kazakhstan: Nature. Economy. Ecology. Almaty [in Russian]. 
Janeczko, E., \& Gucma, M. (2015). The evaluation of the tourist capacity in the Roztoczański National Park. Folia Forestalia Polonica, 57(2), 90-95.

Karatayev, M., Hall, S., Kalyuzhnova, Y. \& Clarke, M.L. (2016). Renewable energy technology uptake in Kazakhstan: Policy drivers and barriers in a transitional economy. Renewable and Sustainable Energy Reviews, 66, 120-136.

Karatayev, M., \& Hall, S. (2017). Integration of wind and solar power in Kazakhstan: Incentives and barriers. In Sustainable Energy in Kazakhstan (pp. 65-89). Routledge.

Koshim, A. G., Sergeyeva, A. M., Saparov, K. T., \& Wendt, J. A. (2019). Development of scientific tourism at Baikonur Cosmodrome Kazakhstan. GeoJournal of Tourism and Geosites, 24(1), 267-279.

Koshim, A., Karatayev, M., Clarke, M. L., \& Nock, W. (2018). Spatial assessment of the distribution and potential of bioenergy resources in Kazakhstan. Advances in Geosciences, 45, 217-225.

Maltceva, N. (2007). Development of methods for environmental and economic analysis and management of the coastal environment. Moscow [in Russian].

Manning, R. (2001). Visitor experience and resource protection: A framework for managing the carrying capacity of national parks. Journal of Park \& Recreation Administration, 19(1), 93-108.

Martin, B. S., \& Uysal, M. (1990). An examination of the relationship between carrying capacity and the tourism lifecycle: Management and policy implications. Journal of environmental management, 31(4), 327-333.

McCool, S. F., \& Lime, D. W. (2001). Tourism carrying capacity: tempting fantasy or useful reality?. Journal of sustainable tourism, 9(5), 372-388.

McLachlan, A., \& Defeo, O. (2017). The ecology of sandy shores (pp. 933-960). Academic Press.

Nakajima, E. S., \& Ortega, E. (2016). Carrying capacity using emergy and a new calculation of the ecological footprint. Ecological Indicators, 6o, 1200-1207.

Nesterova, S., Kokoreva, I., Inelova, Z., Yerubayeva, G., \& Lyssenko, V. (2017). Effect of recreational activities on the main plant communities of the Trans-Ili Alatau. International Multidisciplinary Scientific GeoConference: SGEM: Surveying Geology \& Mining Ecology Management, 17, 289-296.

Papageorgiou, K., \& Brotherton, I. (1999). A management planning framework based on ecological, perceptual and economic carrying capacity: the case study of Vikos-Aoos National Park, Greece. Journal of Environmental Management, 56(4), 271-284.

Rivotti, P., Karatayev, M., Mourão, Z. S., Shah, N., Clarke, M. L., \& Konadu, D. D. (2019). Impact of future energy policy on water resources in Kazakhstan. Energy Strategy Reviews, 24, 261-267.

Saarinen, J. (2006). Traditions of sustainability in tourism studies. Annals of tourism research, 33(4), 1121-1140.

Sakypbek, M., \& Aktymbayeva, A. (2017). Developing and screening sustainable tourism indicators in the Ile-Alatau state national nature park. Journal of International Scientific Publications: Ecology \& Safety, 11, 361-374.

Saparov, K. T., Yeginbayeva, A. Y., Nurgalieva, G. Z., Kulzhanova, S. M., Atasoy, E., \& Wendt, J. A. (2017). The question of Kazakh national and geographical toponymic as a potential factor of tourism development. GeoJournal of Tourism and Geosites, 19(1), 115-125.

Saveriades, A. (2000). Establishing the social tourism carrying capacity for the tourist resorts of the east coast of the Republic of Cyprus. Tourism management, 21(2), 147-156.

Sayan, M. S., \& Atik, M. (2011). Recreation carrying capacity estimates for protected areas: a study of Termessos National Park. Ekoloji, 20(78), 66-74.

Sharma, V. R., \& Kamal, B. (2019). Carrying capacity assessment and sustainable tourism management in Agra city, Uttar Pradesh (India). GeoJournal of Tourism and Geosites, 25(2), 399-407.

Shelby, B. \& Heberlein, T.A. (1984). A conceptual framework for carrying capacity determination. Leisure sciences, 6(4), 433-451.

Singtuen, V., \& Won-In, K. (2018). Geodiversity and geoconservation of the Chaiyaphum region in Thailand for sustainable geotourism planning. GeoJournal of Tourism and Geosites, 22 (2), 548-560.

Valeyev, A., Karatayev, M., Abitbayeva, A., Uxukbayeva, S., Bektursynova, A., \& Sharapkhanova, Z. (2019). Monitoring Coastline Dynamics of Alakol Lake in Kazakhstan Using Remote Sensing Data. Geosciences, 9 (9), 404.

Vujko, A., Plavša, J., Petrović, M. D., Radovanović, M., \& Gajić, T. (2017). Modelling of carrying capacity in National Park - Fruška Gora (Serbia) case study. Open Geosciences, 9(1), 61-72.

Vukolov, V., \& Woodward, D. (2010). Ecotourism expedition to the Ile Alatau National Park. Recreation, tourism and nature in a changing world, 325-326.

Zelt, G. \& Kireev, M. (2012). Feasibility study of the project ski resort Kokzhailau. Almaty [in Russian].

Zhang, L., Chung, S., \& Qiu, J. (2016). Ecological carrying capacity assessment of diving site: A case study of Mabul Island, Malaysia. Journal of Environmental Management, 183, 253-259.

*** Rosgiproles (2009). Report on research work on the basic project 09-U4-01 Develop environmental and economic justifications for the formation of specially protected natural territories of federal significance. Moscow [in Russian].

Submitted:

05.11.2019
Revised:

01.04.2020
Accepted and published online 08.04.2020 